\title{
IMPLEMENTATION OF BLENDED EDUCATION AT THE FACULTY OF PHILOLOGY
}

\author{
Valerii Budak, Svitlana Zaskaleta, Oksana Oleksyuk
}

This study emphasizes the need for innovation in pedagogical theory and practice. It highlights the theoretical and methodological foundations of the organization of blended learning in English teaching. The authors confirm a detailed theoretical basis, offer a model of blended learning in foreign language lessons for FLS. A blended approach to learning is one of the most relevant educational technologies today, as it allows you to take advantage of the flexibility and convenience of distance learning and the benefits of traditional forms of learning. As a result of theoretical analysis and experience of university teachers in a blended form of education, aspects that have remained outside of research are revealed. This includes the methodological potential of the organization of independent cognitive activity of FLS. The realization of this idea is impossible without the development and implementation of appropriate learning technologies.

Three main components of the blended learning model that are used in the modern educational environment are identified:

- face-to-face training (face-to-face) is a traditional format of classroom teacher-student;

- self-study learning - involves independent work of students: search for materials using a resource map, online search, etc .;

- online learning (online collaborative learning) - the work of students and teachers online, for example, through Internet conferences, Skype or wiki, etc.

Keywords: blended learning, distant learning, educational trajectories, independent cognitive activity, organization, interdisciplinary connections, pedagogy

(C) The Author(s) 2021

This is an open access article under the Creative Commons CC BY license hydrate

How to cite:

Budak, V., Zaskaleta, S., Oleksyuk, O. (2021). Implementation of blended education at the faculty of philology. ScienceRise: Pedagogical Education, 4 (43), 47-52. doi: http://doi.org/10.15587/2519-4984.2021.238439

\section{Introduction}

In response to modern challenges (transformation of societies, reduction of education funding, crisis in the humanitarian sphere, quarantine restrictions), the world educational community is solving the problem of ensuring the quality of higher education. The quality of education is not a national but a global problem. According to UNESCO, the XXI century is a century of quality education. Therefore, modern education requires the development and implementation of new educational technologies that can provide quality training. Fulfillment of this task is a particularly important issue for domestic education, which is currently being reformed.

Universities around the world have introduced distance learning, which required a combination and improvement of both traditional and innovative forms of learning.

The National Doctrine of Education Development (2002) states that the strategic goal of state policy is to bring education, acquired in Ukraine, to the market of world educational services, deepen international cooperation, expand the participation of educational institutions, scientists, teachers, pupils, students in international projects, organizations and communities. The main purpose of modern higher education is to train a specialist, competent in the field of their professional activity, capable of effective work in the specialty at the level of world standards, continuous self-improvement and self-development.

That is why the issue of development and implementation of innovative teaching methods in higher education institutions of Ukraine is relevant.

The transition to distance education, in particular in foreign language classes in higher education institutions, is due to today's challenges and is one of the priority areas of public policy in Ukraine in the context of integration of the domestic education sector into the European and world educational space. Ensuring the quality of education, modernization of its content, development and implementation of educational innovations and information technologies, creating conditions for training a specialist, suitable for the effective implementation of innovative tasks of the appropriate level of professional activity, is an urgent task, facing higher education institutions. 
For this reason, the importance of teaching a foreign language in a mixed form of education at the Faculty of Philology is growing.

\section{Literature review}

Maksak I. (2013) [1] devoted his work to the issue of organizing the teaching of future English teachers in the conditions of distance education. The scientist divides them into general didactic, methodical general and special principles for the organization of blended learning. However, in our opinion, the above-mentioned principles are only the basis for the organization of blended learning.

Blended learning and the use of blended learning technologies in quarantine is a new organization of the educational process, which has raised many issues of teachers and administration of higher education, namely. (I. Maksak):

- selection of services and tools for work;

- organization of individual and group work with the use of distance learning technologies;

- assessment of students and control of activity of each of them; learning;

- development or selection of a model of blended

- establishing effective interaction of all participants in the educational process;

- providing communication.

Vorotnikova I. [2, 3] analyzes the experience of introducing distance learning in the educational environment of secondary school. The researcher points to the positive effects and obstacles to the introduction of distance technology in learning. However, ways to improve blended learning remain unexplored.

V. M. Kukharenko, C. M. Berezenska, K. L. Bugaichuk, N. Y. Oliynyk, T. O. Oliynyk, O. V. Rybalko, N. G. Syrotenko, A. L. Stolyarevskaya (2016) [4] in their monograph present the pedagogical technology of designing blended learning and various information technologies to support it on the examples of technical disciplines. The proposed methods of forming critical thinking in blended learning deserve attention.

Oliynyk V. V. [5], considering "open education" offers own model. It provides:

- openness of education in the future; the world;

- integration of all ways of human cognition of

- development and inclusion in the processes of education of synergetic ideas about the openness of the world, the integrity and interconnectedness of human, nature and society;

- free use of information resources;

- personal orientation of the learning process;

- development of information culture;

- methods of evaluating the final results of the educational process.

For a clearer understanding of the potential of this method, consider terminological differentiation.

Foreign experts consider blended learning as:

- a set of technologies and traditional classroom learning based on a flexible approach that takes into account the benefits of training and control tasks in the network, which can significantly improve the quality of learning while reducing the cost of a learning space [6]; - a set of learning processes, provided by personal communication and software technologies within a single learning space [7];

- a course of study that combines personal communication and the use of technology [8].

Nicky Hockly [9] exploring the problem of blended learning, highlights the basic principles of blended learning:

- interaction: includes provisions for online interaction with other students, teachers, and possibly with individuals around the world.

- design and tools of tasks: development of tasks and choice of technological tool you need to answer;

- materials: instead of just providing technologybased content / materials;

- integration: there must be a clear link and integration between them $\mathrm{f} 2 \mathrm{f}$ and technological components of the course with each complementing, supporting and developing others;

- assessment: technology-based work (including oral and / or written) work) must be integrated into the overall assessment of students;

- context: blended learning should take into account local context, including students' needs, skills, expectations and beliefs and teachers;

- teacher training: learning is the key to successful implementation of a mixed approach to make sure that teachers understand the basics principles and are able to effectively implement the mixture;

- student learning: if students consider autonomous work a challenge, the mixture may require initial training of students.

So, blended learning (blended learning technology) is becoming the most popular and effective in the process of teaching a foreign language, because it, on the one hand, allows you to most effectively organize the time of a teacher and a student, and on the other hand, makes the language learning process interesting. Blended learning is not only a combination of certain formal learning tools (working in the classroom, studying and repeating speech material) with informal (discussion of important aspects of learning material via e-mail, Internet platforms and on-line conferences), but also a combination of different tools of educational material presentation (full-time, distance and independent learning).

The above scientific and pedagogical literature has allowed us to gain a deeper and better understanding of blended learning and the participants of the educational process. We have considered the necessary set of external and internal circumstances, aimed at improving the effectiveness of educational and cognitive activities in the new pedagogical environment.

Vilma Bijeikienè, Svetlana Rašinskienè, Lina Zutkienè [10] in there study shows that English teachers show a generally positive attitude towards the mixed teaching. This study shows that English teachers are generally positive about blended learning.

However, they express some doubts about the usefulness of activities in a virtual environment, for example virtual consultations and discussions that can be 
repeated related to their need to improve general ICT awareness.

\section{The aim and objectives of the study}

The purpose of this article is to implement the blended technology education at the Faculty of Philology.

To achieve this aim, it is needed to analyze:

- identification of ways to modernize the system of professional training of specialists at the Faculty of Philology;

- outlining the prospects of development of professional training of specialists in the field of education

- to consider the necessary set of external and internal circumstances, aimed at improving the effectiveness of educational and cognitive activities in the new pedagogical environment.

\section{Materials and methods}

This study was conducted in 2020, i.e. during COVID-19 pandemic. The appropriate research methods have been considered: the theoretical analysis of the above mentioned normative documents; psychological, pedagogical, and methodological literature generalize modern innovative integrated methodological approaches to the development of distance education.

In order to successfully organize the independent educational and cognitive activities of a student in a foreign language class on a mixed form of education there were organized multimedia system e-learning or learning management system. These systems can work in real time, are characterized by a high level of interactivity, contain a huge number of individual and group tasks. The functioning of these systems is provided by "electronic platforms" (online platforms), through which you can create a rich information environment and conditions for active learning of a foreign language.

These studies are based on the experience of students who studied in the form of blended learning. This study aims to determine the level of quality of knowledge of students of the Faculty of Philology of Mykolaiv V. O. Sukhomlinsky National University (Ukraine). Based on the literature review, a model of blended learning was developed. The authors also chose observation, literature analysis, providing results on the level of knowledge of students who studied in this form and descriptive data analysis as research tools.

The model, developed by us, consists of the following ways: organization of theoretical, practical and integrated activities, designed for participants in the educational process in terms of educational competence.

The use of blended learning, which is based on the concept of combining classroom learning and elearning technologies, which is based on new didactic opportunities with the use of information and communication technologies, gives a modern teacher unlimited opportunities in teaching a foreign language. This method of teaching primarily allows for flexibility and accessibility to expand the capabilities of students, to take into account the individual needs, rhythm and pace of learning the material being studied; to stimulate the formation of an active position of a student, to increase his/her motivation, independence, social activity; make the learning process more individual and at the same time personalize it. This helps students to determine their own goals and methods of achieving them, while the teacher acts as a mentor.

The advantages of this technology include the ability to build an individual learning trajectory of a student with a teacher, the possibility of continuous cooperation of students with classmates and the teacher, as well as the responsibility of the student for learning outcomes. In a blended learning environment, a teacher should effectively organize the classroom and independent work of students, create online support for them. Students, in turn, need to clearly define the ultimate goal of learning, to develop an individual learning trajectory, to intensify independent cognitive activity. Thus, a subject-subject relationship is established between a teacher and a student, which ensures the quality of foreign language teaching.

Among the tools of the electronic platform, which are necessary for individual and group research activities of students (for example, preparation of projects, presentations on the proposed topic) we can offer the following:

- chat - a form of group communication on the Internet online;

- blog - Internet diary, its main content (constantly adding posts that contain text or images);

- forum - a set of sections for discussion or exchange of views on certain topics in virtual form;

- wiki - a site on the Internet, the structure and content of which users can change themselves using tools, provided by the site itself.

\section{Results}

In the process of applying this technology during foreign language learning students develop skills and abilities to work in a foreign language information space, independently search, select and analyze information, present the result using various modern technologies, the formation of necessary speech and sociocultural competencies.

However, when introducing innovative methods and technologies into the process of learning a foreign language, one should keep in mind the effectiveness of innovations in the educational process, as innovations require not only a critical approach, but also a complete and thorough analysis. Therefore, there is a need for monitoring research, which will identify difficulties in the planning, organization and content of the educational process, the problems of adaptation of teachers and students to new conditions of the educational environment and after analyzing the situation will help in making appropriate decisions.

\section{Components of the learning model}

Today, the importance of blended learning in higher education is constantly growing. So, in Mykolaiv V. O. Sukhomlinsky National University (Ukraine) in the teaching of foreign languages in particular, blended learning is actively used, as it meets the requirements of modern students, living in the age of electronic technology.

A model of blended learning in a foreign language class has been developed, which consists of the following components: 
Synchronous mode. Interaction between the subjects of distance learning, during which all participants are simultaneously in the web environment of distance learning (chat, audio, video conferencing, social networks)

It includes:

- webinars, video conferences (Zoom, Google Meet, YouTube); Viber).

- messengers (Telegram, Facebook Messenger,

Asynchronous mode. Interaction between distance learning subjects, during which participants interact with each other with a delay in time, using e-mail, Internet platform, forum, social networks, etc. These include:

Viber, etc.);

- messengers (Telegram, Facebook Messenger,

- social networks (Instagram, Facebook);

- assessment of knowledge (Classtime, Google

Forms, Testorium);

- OneDrive cloud services, Google Drive,

YouTube).

The choice of means of information transfer is conditioned by the didactic purposes of training and availability and quality of resources. It is also important to note, that the choice of means of information transmission influences the choice of teaching methods and pedagogical technology.

Students have the opportunity to communicate with the teacher and a group of students in synchronous mode. This is done through video broadcasts. For example, live on the Zoom platform.

In Regulations on the distance form of training in Mykolaiv V.O. Sukhomlinsky National University of pedagogical stuffs are asked to independently determine the synchronous or asynchronous mode for training. At the same time, at least 70 percent of the study time, provided by the educational program of the educational institution, must be provided synchronously. Synchronous mode requires appropriate technical support for both a teacher and all students. There is still a risk of technical failures when individual students complete the task, so all synchronous activities should be recorded in video files and saved. Email reserves are used for this purpose. Asynchronous mode is more flexible to use because students can complete tasks at a convenient time, but it is less objective. To reduce the risks of biased assessment, the option to take a test once and limit the time to complete the task, set a deadline for taking the test (control, practical or independent work, etc.), report the results (in the case of non-automated testing) individually after passing the work is given. If necessary, the teacher can conduct an additional oral interview of students using one of the means of video communication. Practical training, which involves the implementation of practical (control) work, takes place remotely in asynchronous mode. Some practical tasks can be performed synchronously. Depending on the selected digital resources and the distance learning model, the teacher can use open or university resources (distance learning management systems) or both. For example, when working in the Moodle platform, the tools of this platform are used: a description of credits, topics of practical classes, tasks for independent, control works, tasks for conducting a test control of students' knowledge, the list of the basic, additional literature, Internet resources is offered.

Practical classes are focused on the formation of practical skills, competencies, generalization of theoretical material, analysis of language situations. Each task and type of activity, included in the work program of the discipline "Foreign Language", has a direct connection with the planned learning outcomes and promotes students to these results. Assessment of the task, regardless of the form, is based on clear and understandable criteria, set out in the work program of the discipline, with which an applicant is acquainted at the beginning of learning a foreign language.

Implementation of activities - through the university learning management system Moodle (mandatory placement of educational and methodological support of the discipline) with the possible use of tools of synchronous interaction (Zoom, GoogleMeet) and asynchronous interaction (GoogleForms, GoogleDrive, GoogleClass, etc.).

Independent work of students takes place according to the schedule in the online mode (performance of tasks on a higher and wider volume on the basis of the studied educational material, performance of practical tasks, communication by means of information and communication technologies, Moodle system).

Closing of credits in academic disciplines takes place according to a separate schedule (time, audience, teacher, form of credit utilization), in accordance with the curriculum.

Various software products, such as Zoom, GoogleMeet, Skype, Discord, BigBlueButton, etc., are used to monitor student performance and consultations in video mode, taking into account their capabilities and limitations (video session time, number of concurrent users, software requirements. etc).

The use of this model allows to improve the organization of blended learning, thus activating the independent educational and cognitive activities of students in learning a foreign language, as well as facilitates the introduction of interdisciplinary links, knowledge exchange and dissemination of experience at intrauniversity and inter-university levels, material for students of both large cities and small towns.

Further research work. The strategy for the development of blended learning is based on the fact that blended learning is a new educational paradigm, and is based on the readiness of an organization to implement this form of learning. Practice shows that the greatest effect is achieved only by combining traditional face-toface and distance learning. A flexible system of electronic testing contributes to the systematic control of students' knowledge. The use of blended learning leads to increased interest of students in learning, because there is a natural assimilation of modern means of communication and means of work organization, which contributes to the development of information and communication competence of students.

\section{Conclusions}

Blended learning is the integration of online learning with traditional classroom learning. It involves the use of two or more different teaching methods, such as alternating face-to-face classes with online learning. 
1. A blended approach to learning is one of the most relevant educational technologies today, as it allows you to take advantage of the flexibility and convenience of distance learning and the benefits of traditional forms of learning.

2. Blended quarantine training is a new organization of the educational process, which is determined by the implementation of the following components, namely:

- choice of services and tools for work;

- organization of individual and group work with the use of distance learning technologies;

- assessment of students and control of each of them; learning;

- development or selection of a model of blended

- establishing effective interaction of all participants in the educational process;

- ensuring communication.
3. Among the main ways to improve philological education are the following:

- development of a model of blended learning based on the improvement of distance synchronous and asynchronous learning;

- introduction of modern pedagogical technologies and scientific and methodological achievements into the educational process

4. Blended learning combines the best experiences of traditional learning and interactive cooperation on the Internet, is a system that works in constant correlation and forms a single whole. The use of blended learning method qualitatively changes the content of foreign language learning. The variety of resources of the electronic component of the mixed course opens new opportunities for the presentation of educational material, allows students to determine an individual trajectory of study independently.

\section{References}

1. Maksak, I. (2013). "Blended learning" as an innovative approach in the process of primary english teacher profossional competence formation. Visnyk Chernihiv. nats. ped. un-tu im. T. H. Shevchenka. Seriya: pedahohichni nauky, 110, $247-249$.

2. Vorotnykova, I. P., Yakubov, S. V. (2017). Uprovadzhennia dystantsiynykh tekhnolohiy u navchalno-vykhovnyi protses zahalnoosvitnikh navchalnykh zakladiv. Kyiv: Kyiv, un-t im. B. Hrinchenka, 140.

3. Vorotnykova, I. P. (2014). Information and educational environment for various forms of education in modern school. Informatyka ta informatsiyni tekhnolohiyi v navchalnykh zakladakh, 6 (54), 3-10.

4. Kukharenko, V. M., Berezenska, S. M., Buhaichuk, K. L., Oliynyk, N. Yu., Oliynyk, T. O., Rybalko, O. V. et. al.; Kukharenko, V. M. (Ed.) (2016). Teoriya ta praktyka zmishanoho navchannia. Kharkiv: «Miskdruk», NTU «KhPI», 284.

5. Oliynyk, V. V. (2013). Vidkryta pisliadyplomna pedahohichna osvita ta dystantsiyne navchannia u zapytanni ta vidpovidachakh. Kyiv: «A.S.K», 312.

6. Tomlinson, B., Whittaker, C. (Eds.) (2013). Blended Learning in English Language Teaching: Course Design and Implementation. London. Available at: https://www.teachingenglish.org.uk/sites/teacheng/files/pub_D057_Blended\%20learning_FINAL_ WEB\%20ONLY_v2.pdf

7. Bañados, E. (2013). A Blended-learning Pedagogical Model for Teaching and Learning EFL Successfully Through an Online Interactive Multimedia Environment. CALICO Journal, 23 (3), 533-550. doi: https://doi.org/10.1558/cj.v23i3.533-550

8. Stracke, E. (2007). A road to understanding: A qualitative study into why learners drop out of a blended language learning (BLL) environment. ReCALL, 19 (1), 57-78. doi: https://doi.org/10.1017/s0958344007000511

9. Hockly, N. (2018). Blended Learning. ELT Journal, 72 (1), 97-101. doi: https://doi.org/10.1093/elt/ccx058

10. Bijeikienè, V., Rašinskienè, S., Zutkienè, L. (2011). Teachers' Attitudes Towards the Use of Blended Learning in General English Classroom. Studies About Languages, 18, 122-127. doi: https://doi.org/10.5755/j01.sal.0.18.420

Received date 11.05.2021

Accepted date 08.06.2021

Published date 30.07.2021

Valerii Budak, Doctor of Technical Sciences, Professor, Academician of National Academy of Educational Sciences of Ukraine, Rector, V. O. Sukhomlynskyi National University of Mykolaiv, Nikolska str., 24, Mykolaiv, Ukraine, 54030

Zaskaleta Svitlana, Doctor of Pedagogy Sciense, Associate Professor, Department of English Language and Literature, V. O. Sukhomlynskyi National University of Mykolaiv, Nikolska str., 24, Mykolaiv, Ukraine, 54030

Oleksyuk Oksana*, $\mathrm{PhD}$, Associate Professor, Department of Pedagogy and Inclusive Education, V. O. Sukhomlynskyi National University of Mykolaiv, Nikolska str., 24, Mykolaiv, Ukraine, 54030

*Corresponding author: Oleksyuk Oksana, e-mail: oleksjukoksana@ukr.net 